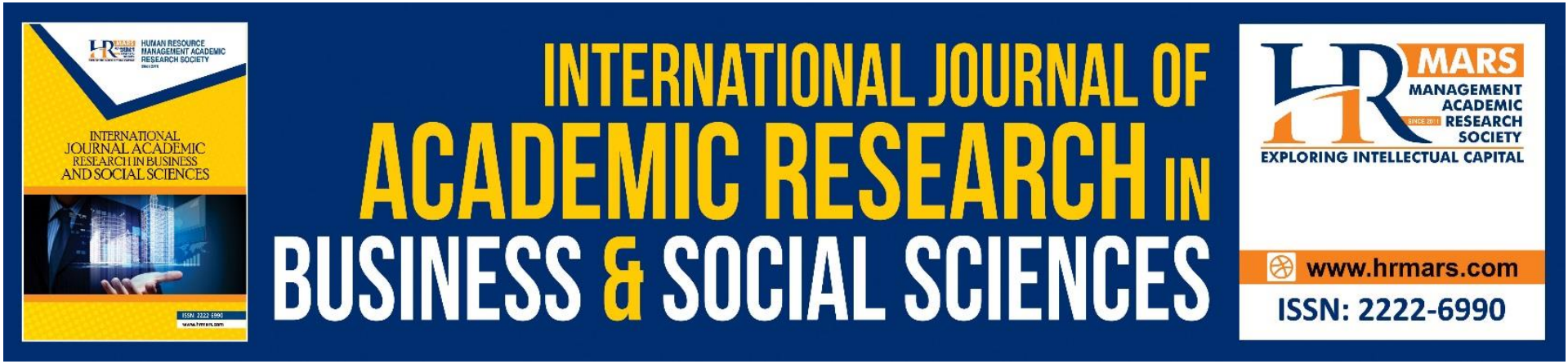

\title{
Analysis on the Readiness of Vocational College Lecturers to Implement OBE Approach
}

Shuhada Abdul Raof, Aede Hatib Musta'amal @ Jamal, Nurul Ain Saipudin

To Link this Article: http://dx.doi.org/10.6007/IJARBSS/v12-i1/12061

DOI:10.6007/IJARBSS/v12-i1/12061

Received: 13 November 2021, Revised: 18 December 2021, Accepted: 28 December 2021

Published Online: 25 January 2022

In-Text Citation: (Raof et al., 2022)

To Cite this Article: Raof, S. A., Jamal, A. H. M. @, \& Saipudin, N. A. (2022). Analysis on the Readiness of Vocational College Lecturers to Implement OBE Approach. International Journal of Academic Research in Business and Social Sciences, 12(1), 1489 - 1505.

Copyright: @ 2022 The Author(s)

Published by Human Resource Management Academic Research Society (www.hrmars.com)

This article is published under the Creative Commons Attribution (CC BY 4.0) license. Anyone may reproduce, distribute, translate and create derivative works of this article (for both commercial and non0-commercial purposes), subject to full attribution to the original publication and authors. The full terms of this license may be seen at: http://creativecommons.org/licences/by/4.0/legalcode

Vol. 12, No. 1, 2022, Pg. $1489-1505$

Full Terms \& Conditions of access and use can be found at http://hrmars.com/index.php/pages/detail/publication-ethics 


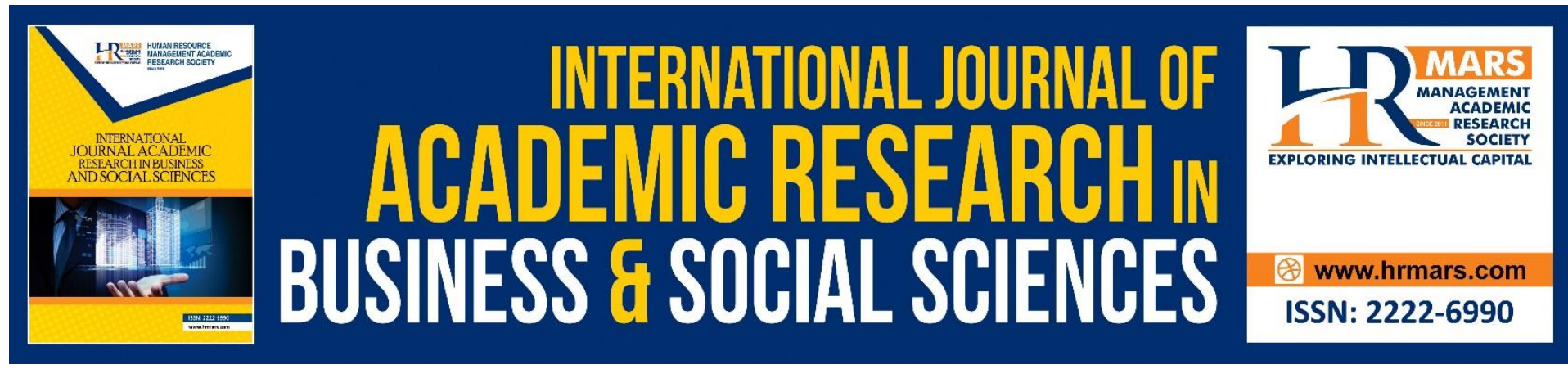

\title{
Analysis on the Readiness of Vocational College Lecturers to Implement OBE Approach
}

\section{Shuhada Abdul Raof, Aede Hatib Musta'amal @ Jamal, Nurul Ain Saipudin}

School of Education, Universiti Teknologi Malaysia, 81310 Skudai, Johor, Malaysia

Email: shuhada2@graduate.utm.my

\begin{abstract}
This study was conducted to analyse the readiness of Vocational College (KV) lecturers in teaching and learning. The outcome-based education (OBE) approach in vocational colleges brings about changes to the vocational education system in line with the transformation of TVET. OBE is a method of teaching and curriculum design that focuses on learning outcomes. This method has completely replaced the conventional method, which is more centred on examination alone. However, the extent to which KV lecturers understand and are willing to practice OBE in curriculum delivery is yet to be discovered. This study was a quantitative study that used a set of questionnaires as a research instrument. The respondents of this study consisted of 368 lecturers of KV throughout Malaysia. Data collected using questionnaire instrument were analysed using Statistical Package for The Social Science (SPSS) software. The results from the analysis of the study data demonstrated that the level of understanding of $K V$ lecturers on the implementation of OBE approach was at a high level with a mean score of 3.07. Meanwhile, the level of readiness of KV lecturers on the implementation of OBE approach was at a moderate level, which has a mean score of 2.82.
\end{abstract}

Keywords: Outcome-Based Education, Vocational College, Lecturer, Learning Outcomes

\section{Introduction}

Changes in Malaysia's educational system are no longer new. These changes are intended to ensure that a system is relevant to the country's current flow of development. This is in line with TVET's transformation in the vocational educational system that focuses on the transformation of the vocational colleges. This transformation does not only bring about a change in the name itself, but also a change in the system of teaching methods used. Existing conventional methods that incorporate achievement through objectives have turned to achievement through outcome-based education. In Malaysia, OBE is implemented at all levels of education in institutions of higher learning including vocational colleges. According to Hassan et al (2016) this paradigm shift is driven by the Malaysia Quality Agency (MQA) at the Ministry of Education, Malaysia (MoE). This agency has been given the responsibility to develop and implement a national framework for education, which outlines nine learning outcomes (LO). The OBE is also being implemented in 85 vocational colleges throughout Malaysia. The implementation of OBE is seen relevant for Vocational Colleges since the 
transformation of TVET in Malaysia has changed the education system in vocational colleges. This new system requires the OBE to be implemented to allow the diploma obtained by Vocational College graduates to have MQA accreditation value, which in turn qualifies them to work in the public sector and continue their studies at a higher level. Therefore, the implementation of OBE in Vocational Colleges is seen as significant and requires major changes in all aspects especially in terms of readiness of the lecturers. From the context of this study, KV lecturers are the implementers of all policies and goals set by the ministry. Therefore, the lecturers are a team that needs to understand, master and be prepared in delivering teaching and learning using the OBE approach.

Outcome-based Education (OBE) refers to a well organised and focused educational system within the education system on the achievement of students at the end of a learning (Spady, 1994). OBE is a method of teaching and curriculum design that focuses on learning outcomes. Through this method, students need to plan, implement and present learning outcomes at the end of the learning. This system has gradually replaced the conventional, objective-based teaching method. OBE is a change conceived and developed by William G. Spady. According to Spady and Marshall (1991), OBE is based on three principles; first, all students can learn and succeed but not at the same time. Second, the success of an institution will produce another success and the third, an institution has a full autonomy in shaping success.

According to Tucker (2004), this OBE is a learning process involving curriculum reorganisation, assessment practice and reports in the field of education to achieve learning outcomes and mastery of what is learned through credit collection. This is supported by the study of Murad and Hamzah (2016) which states that OBE is also linked to an approach that leads to curriculum development where improvements to the curriculum are constantly implemented so that students can achieve the output of the programme. OBE is a new student-centred approach that enables students to be creative and critical rather than solely centred by lecturers. Outcome-based education (OBE) is an education that uses student-centred teaching and learning methods. In the context OBE approach, each course offered should provide the learning outcomes that can be achieved by students after attending a programme or course of study. This opinion is supported by the study of Dahdi and Iksan (2018) who asserted that OBE is a student-centred learning system that focuses not only on student final exam results (cognitive domain), but also on other learning outcomes (psychomotor and affective domains) throughout the process. This is also in line with Damit and Omar (2018) study, which stated that the implementation of this OBE was a positive change as studentcentred learning $(\mathrm{SCL})$ and teaching were evaluated not only on cognitive, but also psychomotor, affective and social aspects during their study at vocational college. OBE is a student-centred teaching and learning method that is now widely adopted at Vocational College. The system has begun to replace existing systems for enhancing the effectiveness of learning outcomes that will be measured based on students' knowledge and skills. OBE gives students the opportunity to better understand and learn a field of study as it focuses on the results to be achieved and does not rely on traditional approaches. This coincides with the opinion of Zain et al (2016) who stated that each individual has different ways and strategies of learning in different situations. OBE gives students the freedom to learn a content of study using appropriate methods. In OBE, key content needs to be identified first and followed by methods to study it Borsoto et al (2014) ummarized OBE in three main points: students need to know why they are learning whatever they are learning, they need to see some value in this learning, and they need to believe that they can be successful. 
The outcome-based curriculum emphasises on the teaching and learning environment as well as assessment that focuses on students. In the long term, the student-centred learning environment will produce graduates with lifelong learning skills and develop independent, creative and innovative graduates. This view is in line with the transformation of the vocational college that dreams of vocational college graduates who are creative and innovative. OBE was first introduced at vocational colleges when vocational and technical high schools were upgraded to vocational colleges. The OBE approach at vocational college is adopted to meet the requirements of the Malaysian Qualifications Agency (MQA) to recognise diploma programmes implemented to meet the standards set. Implementing the OBE approach in vocational college is not an easy step to take. Various challenges and obstacles must be met to ensure that all vocational college students can master the importance and implementation of OBE.

\section{OBE implementation in Vocational College}

The branding of vocational secondary schools to Vocational College (KV) began in 2012 with the implementation of Vocational Education Transformation. KV is a post-secondary vocational education and training institution that implements the Vocational College Standard Curriculum (KSKV) to create a vibrant, knowledgeable and highly skilled human capital. This transformation is seen as a process of restructuring the existing education system to reflect various changes in the new paradigm of the country. Beginning in 2016, the OBE approach became the focus of vocational college communities when the programmes offered required the recognition from the Malaysian Qualifications Agency (MQA) to meet the established standard. OBE approaches such as the Programme Educational Objective (PEO), the Programme Learning Outcome (PLO) and the Course Learning Outcome (CLO) have begun to gain the attention of the college. PEO can be described as the students' direction after four to five years of graduation from vocational college. There are four PEOs that students need to achieve, namely i. PEO 1: knowledgeable and skilled in the discipline of knowledge, ii. PEO 2: affective in communication and display good characteristics of leadership in an organisation, iii. PEO 3: able to solve operational problems ethically and iv. PEO 4: able to practice entrepreneurial skills and lifelong learning in line with environmental change. The PLO, on the other hand, could be described as the students' future after graduating the vocational college. Table 1 shows the PEO-PLO mapping matrix in vocational colleges.

Table 1

PEO-PLO mapping matrix

\begin{tabular}{lllll}
\hline \multirow{2}{*}{ Programme Learning Outcome (PLO) } & \multicolumn{5}{l}{ Programme Educational Objective (PEO) } \\
& PEO1 & PEO2 & PEO3 & PEO4 \\
\hline PLO 1 (Knowledge) & $\mathrm{V}$ & & \\
PLO 2 (Practical Skill) & $\mathrm{V}$ & & $\mathrm{V}$ & \\
PLO 3 (Problem Solving) & & & & \\
PLO 4 (Communication Skill) & & $\mathrm{V}$ & & \\
PLO 5 (Teamwork) & $\mathrm{V}$ & $\mathrm{V}$ & $\mathrm{V}$ \\
PLO 6 (Etiquette) & & & & $\mathrm{V}$ \\
PLO 7 (Lifelong Learning) & & & & \\
PLO 8 (Entrepreneurship) & & $\mathrm{V}$ & & \\
PLO 9 (Leadership) & & & & \\
\hline
\end{tabular}


According to Damit and Omar (2018) in the Malaysian Qualification Framework (MQF), each PLO must contain three main learning domains namely Cognitive Domain (knowledge), Psychomotor Domain (skill) and Affective Domain (value). These three domains need to be mentioned during the CLO construction process that guides the lecturers in teaching and learning using OBE concept. The elements of the PLO, PEO and CLO are related to each other and need to clearly state what students should achieve at the end of the programme. The clear, straightforward outcomes provided by OBE form a framework for decision making and guidelines for assessment and program evaluation (Butler, 2006). The vocational college learning system is implemented according to semesters where the annual period is divided into two semesters equal to 14 weeks of teaching and learning with 6 weeks of final assessment period for a semester. At the beginning of a semester, students will be provided with course outline (CO), which is a guide where the content is about the learning outcomes, content and the evaluation of the course. Theoretically, CO is a document that acts as a guideline and agreement between lecturers and students for a particular course taken. Therefore, $\mathrm{CO}$ needs to be explained in full and detailed on the first day of the first week of teaching and learning in that semester. The Programme Accreditation Code of Practice had addressed the need for lecturers to diversify their learning and teaching methods to achieve the eight domains of MQF learning. This is to ensure that students are more responsible for learning and teaching based on results and credit following the national Self Learning Time (SLT). Curriculum delivery is a process of achieving programme learning outcomes and is supported by assessment. Presentation is a process that involves teaching, assessing, facilitating, recording and reporting the teaching and learning process (Malaysian Qualifications Agency, 2011). This situation clearly shows that in ensuring that the quality of a program continues to be accredited, the practice of OBE in the education system of vocational colleges needs to be improved. Therefore, this study is seen as very suitable to be conducted to ensure that OBE can be implemented continuously by Vocational College lecturers.

\section{Readiness of Vocational College Lecturers on OBE Approach}

The teaching and learning method implemented at Vocational College was a conventional method based on teacher-centred learning methods. Some preliminary findings showed that conventional methods produced passive and non-creative graduates in dealing with problems. This is supported by Arifin (2013) who stated that the graduates from conventional teaching patterns were passive and like to wait to be spoon-fed by their teachers. Therefore, this teaching method needs to be changed to ensure that graduates in the job market are able to be competitive, creative and innovative in line with national progress. Therefore, a study needs to be conducted to determine whether or not the OBE teaching method is being implemented by lecturers. This is to ensure that the elements of innovation, creativity, competitiveness, ability to work in a team, communication skills, entrepreneurship and leadership are successfully applied to students in the process.

According to Kamus Dewan, readiness can be interpreted as a matter of preparedness, willingness and volition. Mok (2008) stated that readiness is the ability of an individual to prepare himself to initiate a teaching and learning activity, which can be divided into cognitive, psychomotor and affective readiness. According to Suhaimi (2013), willingness to change is defined as an individual's resistance to behaviour or support for the effort to change. In the context of this study, readiness can be interpreted as the ability and willingness of vocational college lecturers to accept changes in cognitive, psychomotor and affective 
aspects. This is supported by the study of Izham \& Sufean (2015) who emphasised that knowledge, skills and attitudes are three factors that influence readiness for change. This opinion was further reinforced by Fadhlina (2016) who stated that knowledge and skills are the key factors in a planned process of change that need to be faced by front liners such as teachers and management in the field to be developed. In this context, it is clear that lecturers are the main drivers for the implementation of OBE in vocational colleges. Lecturers need to be prepared to clearly understand the concept of OBE to translate the curriculum provided to students with responsibility. To ensure that this approach is truly implemented, a study on the readiness of Vocational College lecturers needs to be conducted.

\section{Problem Statement}

Conventional teaching methods have been long used in teaching and learning activities in vocational and technical secondary schools. It has been publicly known about TVET transformation in Malaysia that has transformed almost all of the SMVs and SMTs into KVs. However, these transformations continue to retain the same teaching staff who are still comfortable practicing the conventional method despite the use of student-centred elements. The Vocational Technical Education and Training Division (BPLTV), the Vocational College, the management and the administration must face various challenges to make this transformation possible. The biggest challenge is to gain the support and confidence of each lecturer in introducing the OBE approach. Not all lecturers are ready to accept the OBE approach as they are still inclined to use the old teaching method. This situation prompted a research related to the readiness and understanding of Vocational College lecturers in applying OBE in their teaching process. This study is seen as suitable to be implemented to ensure that the OBE approach continues to be implemented in the teaching process in Vocational Colleges.

Accordingly, the understanding and readiness of KV lecturers regarding OBE need to be fully appreciated for the teaching and learning process to be implemented. Elements in OBE such as CLO, PLO, PEO, SLT, CO and CQI (continuous quality improvement) need to be mastered and fully understood by lecturers so that this process can produce creative and innovative graduates. The need for skills in a variety of teaching and learning methods and techniques is very important in implementing the OBE approach. Therefore, a study was conducted to determine the extent of KV lecturers' appreciation in the context of understanding and readiness on the practice using $O B E$ approaches in teaching and learning process dimension

\section{Methodology}

Quantitative study is a research process to produce a scientific report for solving problems in specific disciplines. This study is a fully quantitative study in which the research method used questionnaire instrument and involved the measurement of study variables through statistical description. The instruments of the study were designed to analyse the understanding and readiness of KV lecturers in implementing OBE approach in the teaching and learning dimensions. The data obtained was categorised as quantitative data as the production of data involved frequency and percentage as well as mean score analysis.

\section{Population and Samples}

Study population describes the overall position of each individual in a group to be studied. Meanwhile, the sample of a study is taken from the population; little or no sample to be taken depends on the type of study or methodology used. According to Creswell (2012), population 
is the group of people having one characteristic that distinguish them from other groups. Identifying the right method to select the study sample is important as the generalization corresponds to the population. The total number of teaching staff in vocational colleges was approximately around 6,582 people (Arshad \& Mustapha, 2017).

Krejcie and Morgan (1970) stated that the determination of a total study sample is based on the total population. Based on the table of Krejcie and Morgan (1970), the number of appropriate study sample for a population of approximately 7000 people is 368 people. Sample selection was made using a simple random sampling method as it allows all lecturers to have the same opportunity to answer the research questions. This statement is supported by Darusalam and Hussin (2018) who stated that in a simple random sampling method, everyone has the same opportunity to be selected. This sample selection method was carried out by listing 85 vocational colleges and drawing lots for eight vocational colleges. Each selected Vocational College was provided with 100 questionnaires. Simple random sampling is suitable to be used in this study since it has a large population of respondents with the names of lecturers that are difficult to obtain. Therefore, eight selected colleges were drawn for this study.

\section{Study Instrument}

This study was conducted using a set of questionnaires. Questionnaires are often used to determine one's attitude using open-ended questions, checklists or rating scales (Darusalam \& Hussin, 2018) An instrument is a research tool for obtaining data in a research setting. Questionnaire is a data collection tool or instrument used in quantitative research. Content validity means that the content of a measuring instrument is able to obtain feedback on the entire domain of knowledge, skills, attitudes and behaviours measured by the instrument used (Cohen et al., 2000) Meanwhile, facial validity can be defined as the extent to which the measurements made can measure the actual value to be measured. This is to ensure that the instrument built is good and can measure the actual value. In this study, the study questionnaire was reviewed and confirmed by three experts consisting two content validation experts that comprised a lecturer in the field of Outcome-based education and a Head of Department Vocational College. As for facial validation, it involved a language lecturer as a face validation expert. The distribution of the questionnaire to be used is shown in Table 2 .

Table 2

Study Instrument

\begin{tabular}{|c|c|c|c|c|}
\hline $\begin{array}{l}\text { Design of } \\
\text { study }\end{array}$ & Instrument & & & $\begin{array}{l}\text { Number of } \\
\text { items }\end{array}$ \\
\hline & & Section A & Demography & 5 \\
\hline \multirow[t]{3}{*}{ Quantitative } & Questionnaire & Section B1 & Understanding & 10 \\
\hline & & Section B2 & Readiness & 10 \\
\hline & & Section C & Constraint & 5 \\
\hline Total & & & & 30 \\
\hline
\end{tabular}


As for the reliability of this instrument, it was shown that the value of Cronbach's Alpha coefficient was 0.87 , which indicates that this questionnaire is consistent and has a high reliability. There are five ranges in instrument reliability where Hair et al (1998) have outlined that a reliability value equal to or greater than 0.7 can be used as a study instrument. However, if it has a value equal to or less than 0.6 , it is less appropriate and needs to be modified. This study used two types of item in the research questionnaire. Multiple choices and four-point scale items were selected. Questions that used multiple choice items include lecturers' name of office, gender, department name, time of service and teaching stream in $\mathrm{KV}$. Whereas to analyse the data from respondents of the study for understanding and readiness items, four-point scale item was used. The four-point scale used four scales where each scale was assigned with a corresponding score of $1=$ Strongly Disagree, $2=$ Disagree, 3 = Agree, 4 = Strongly Agree. For items used to identify the constraints faced by the lecturers, two-point scale was used with 1 = Agree, 2 = Disagree.

\section{Data Analysis Method}

Data analysis of this study was done using the Statistical Package for Social Science (SPSS). According to Darusalam and Hussin (2018) analysing statistical data using SPSS programming software can produce accurate calculation. According to Chua (2014), nominal and ordinal scale data expressed as categories are used in non-parametric test analysis. The data obtained in this study were presented in descriptive form to see their frequency, mean and percentage. This study used a four-point scale to enable respondents to make informed choices. This scale has been modified according to the mean rating so that the values shown are not too small. The mean rating was made by taking the highest mean values and the lowest mean values. The highest mean values are subtracted from the lowest mean values and then improved according to the study (Chua, 2014). The ranking of mean score was re-evaluated into values that represent the levels of role, namely high, medium and low. These levels of role were used only in the comprehension (Table 5) and readiness (Table 6) sections. The calculation for the mean rating in this study is shown as follows:

$$
\frac{4 \text { (highest mean value) }-1 \text { (lowest mean value) }}{3}=1.00
$$

Frequency levels were re-encoded into the three scales as shown below:

Table 3

Mean Rating Score for 4 Likert Scale

\begin{tabular}{ll}
\hline Mean & Role Level \\
\hline 3.01 to 4.00 & High \\
2.01 to 3.00 & Intermediate \\
1.00 to 2.00 & Low \\
\hline
\end{tabular}

\section{Findings}

The findings and discussion of this study involved respondents background and their knowledge about outcome-based education (OBE). A total of 800 questionnaires were distributed to vocational college lecturers throughout Malaysia. 429 forms were returned successfully, and 368 questionnaires were analysed in this study. This section discusses the results of the analysis obtained from the respondents' questionnaire forms. The process of 
data analysis and decisions made were based on the scope of the planned study. This analysis is divided into sections namely Part I and Part II. Part I deals with the demographics while part Il answers the objectives of this study.

\section{Demographic Analysis of Respondents}

A total of 368 questionnaire forms were processed in this study involving lecturers of vocational colleges throughout Malaysia. The demographic information of the respondents was analysed using SPSS through percentage and frequency distribution. Table 4 shows the respondents' information by gender and teaching experience. Results from the survey found 148 male lecturers (40\%) and 220 female lecturers (60\%) who were selected as respondents of this study. The number of respondents based on their teaching experience found that 139 lecturers $(37.8 \%)$ had served less than five years. 55 of them (15\%) were lecturers who had served between six and 10 years. 57 lecturers (15.6) had served for 11 to 15 years. 39 lecturers $(10.6 \%)$ had served between 16 and 20 years while 78 lecturers (21\%) had served for over 21 years.

Table 4

Demographic of respondents

\begin{tabular}{lll}
\hline Demographic & Percentage & Frequency \\
\hline Gender & & \\
Male & $40 \%$ & 148 \\
Female & $60 \%$ & 220 \\
Serving Period & & \\
$1-5$ years & $37.8 \%$ & 139 \\
$6-10$ years & $15 \%$ & 55 \\
$11-15$ years & $15.6 \%$ & 57 \\
$16-20$ years & $10.6 \%$ & 39 \\
21 years above & $21 \%$ & 78
\end{tabular}

\section{Analysis on the understanding of vocational college lecturers in the implementation of OBE approach}

Table 5 shows the mean and level of understanding of KV lecturers in implementing teaching and learning using the OBE approach. These results indicated that a large number of respondents agreed that they need to implement the OBE approach in the teaching and learning. The data displayed the mean that was at a high level (mean $=3.27$ ). This situation clearly shows that lecturers in Vocational Colleges are aware that they need to implement OBE in their teaching process. However, there were two items that were at a moderate level, namely the lecturers' understanding of the OBE approach through the briefing organised with the mean value of 2.97. Meanwhile, for item namely the motivation to implement teaching and learning using OBE, it was at a moderate level with a mean value of 2.97. Nevertheless, through this data analysis, medium level items were seen to approach high levels. Overall, the data showed that KV lecturers' understanding of OBE approach was at a high level with the overall mean score at 3.07. This data analysis explains that the understanding of KV lecturers on OBE is high, thus suggesting that the KV lecturers have their awareness, knowledge, understanding and motivation on the implementation of OBE. This analysis can be clearly observed in Table 5 
Table 5

Mean and level of understanding of KV lecturers in OBE

\begin{tabular}{|c|c|c|}
\hline Item & Min & Level \\
\hline \multicolumn{3}{|l|}{ I realise that I need to: } \\
\hline $\begin{array}{l}\text { Implement teaching and learning using } \mathrm{OBE} \\
\text { approach }\end{array}$ & 3.27 & High \\
\hline \multicolumn{3}{|l|}{ I know: } \\
\hline $\begin{array}{l}\text { the relationships between PEO, PLO, CLO, LO and } \\
\text { outcome-based assessment }\end{array}$ & 3.07 & High \\
\hline $\begin{array}{l}\text { the concept of F2F, NF2F and formal assessment in } \\
\text { the context of SLT }\end{array}$ & 3.12 & High \\
\hline content that must be contained in $\mathrm{CO}$ & 3.17 & High \\
\hline $\begin{array}{l}\text { theoretically how to design teaching methods to } \\
\text { achieve CLO }\end{array}$ & 3.02 & High \\
\hline $\begin{array}{l}\text { how CLO and PLO are achieved at the end of a } \\
\text { programme }\end{array}$ & 3.01 & High \\
\hline $\begin{array}{l}\text { how OBE can promote innovation in teaching and } \\
\text { learning }\end{array}$ & 3.02 & High \\
\hline $\begin{array}{l}\text { how OBE approach succeeds in producing students } \\
\text { who are successful and balanced in terms of } \\
\text { cognitive and psychomotor as well as affective. } \\
\text { I understand: }\end{array}$ & 3.11 & High \\
\hline $\begin{array}{l}\text { the OBE approach through the organised briefing } \\
\text { I'm motivated to: }\end{array}$ & 2.97 & Intermediate \\
\hline \multirow[t]{2}{*}{ implement teaching and learning using $\mathrm{OBE}$} & 2.97 & Intermediate \\
\hline & 3.07 & High \\
\hline
\end{tabular}

Analysis on the Readiness of Vocational College Lecturers in Implementing OBE

Table 6 displays the mean and level of readiness of vocational college lecturers in implementing OBE approach. Overall, the data indicated that KV lecturers' readiness to implement OBE was moderate (overall mean $=2.82$ ). The data indicated that a significant number of respondents were willing to attend courses/seminars aimed at improving teaching and learning performance using the OBE approach (mean $=3.22$ ). However, in this study, the data showed seven items that were in the medium level with two items that were almost at the low level, which were related to lecturers' readiness if they are selected for interview by the MQA evaluation panel (mean = 2.49). The next item was related to the readiness of the lecturers in explaining how CLO, PLO and PEO can be achieved by KV students and graduates (mean $=2.50)$, which was found to be at a relatively low level in this study. These results indicate that there are still a handful of lecturers who are not yet ready to face the implementation of OBE in meeting the requirements of the MQA. Apart from that, the lecturers are still not ready to move forward to theoretically discuss how KV students and graduates can achieve CLO, PLO and PEO. The results of this analysis on whether or not the lecturers have sufficient input towards implementing teaching and learning using $\mathrm{OBE}$ approach was seen at a moderate level (mean $=2.53$ ). This situation indicates that the KV lecturers still do not have sufficient mastery of OBE in teaching and learning. Overall, the data showed that the readiness of KV lecturers in performing OBE was at a moderate level (overall 
mean $=2.82$ ). These results indicate that the lecturers' input related to OBE and the readiness of the lecturers in explaining the OBE elements are still at a moderate level. This analysis can be clearly seen in Table 6 .

Table 6

Mean and level of readiness of KV lecturers in implementing OBE

\begin{tabular}{|c|c|c|}
\hline Item & Min & Level \\
\hline $\begin{array}{l}\text { I realise that I need to: } \\
\text { Implement teaching and learning using OBE } \\
\text { approach }\end{array}$ & 3.27 & High \\
\hline $\begin{array}{l}\text { I know: } \\
\text { the relationships between PEO, PLO, CLO, LO and } \\
\text { outcome-based assessment }\end{array}$ & 3.07 & High \\
\hline $\begin{array}{l}\text { the concept of F2F, NF2F and formal assessment in } \\
\text { the context of SLT }\end{array}$ & 3.12 & High \\
\hline content that must be contained in $\mathrm{CO}$ & 3.17 & High \\
\hline $\begin{array}{l}\text { theoretically how to design teaching methods to } \\
\text { achieve CLO }\end{array}$ & 3.02 & High \\
\hline $\begin{array}{l}\text { how CLO and PLO are achieved at the end of a } \\
\text { programme }\end{array}$ & 3.01 & High \\
\hline $\begin{array}{l}\text { how OBE can promote innovation in teaching and } \\
\text { learning }\end{array}$ & 3.02 & High \\
\hline $\begin{array}{l}\text { how OBE approach succeeds in producing students } \\
\text { who are successful and balanced in terms of } \\
\text { cognitive and psychomotor as well as affective. }\end{array}$ & 3.11 & High \\
\hline $\begin{array}{l}\text { I understand: } \\
\text { the OBE approach through the organised briefing }\end{array}$ & 2.97 & Intermediate \\
\hline $\begin{array}{l}\text { I'm motivated to: } \\
\text { implement teaching and learning using OBE }\end{array}$ & 2.97 & Intermediate \\
\hline & 3.07 & High \\
\hline
\end{tabular}

\section{Analysis on the Constraints Faced by Vocational College Lecturers in Implanting the ONE} Approach

Table 7 presents the analysis of the constraints faced by KV lecturers in implementing the OBE approach. Based on this analysis, it was clear that 343 respondents (93.2\%) agreed that limited teaching and learning materials have interfered with the planning process using the OBE approach. Meanwhile, shortage of infrastructures such as lecture halls, workshops and inadequate basic equipment hampered the implementation of OBE as 333 respondents $(90 \%)$ agreed with this item. For the next constraint item, the respondents disagreed with the constraint as shown in Table 7. 
Table 7

Mean and level of readiness of KV lecturers in implementing OBE

\begin{tabular}{|c|c|c|}
\hline Item & Min & Level \\
\hline $\begin{array}{l}\text { I have: } \\
\text { adequate input towards teaching and learning } \\
\text { using OBE approach }\end{array}$ & 2.53 & Intermediate \\
\hline $\begin{array}{l}\text { KV responsible for encouraging lecturers to use } \\
\text { OBE approaches in teaching and learning }\end{array}$ & 3.12 & High \\
\hline $\begin{array}{l}\text { I'm ready to: } \\
\text { participate in courses/seminars aimed at } \\
\text { improving teaching and learning performance } \\
\text { using the OBE approach }\end{array}$ & 3.22 & High \\
\hline $\begin{array}{l}\text { be invited to design teaching and learning } \\
\text { materials using the OBE approach }\end{array}$ & 2.86 & Intermediate \\
\hline take the opportunity to brief students on OBE & 2.71 & Intermediate \\
\hline $\begin{array}{l}\text { face the challenge of implementing OBE in teaching } \\
\text { and learning }\end{array}$ & 3.00 & Intermediate \\
\hline $\begin{array}{l}\text { apply teaching methods in teaching and learning } \\
\text { using the OBE approach }\end{array}$ & 3.04 & High \\
\hline be selected for interview by the MQA Review Panel & 2.49 & Intermediate \\
\hline $\begin{array}{l}\text { explain how CLO, PLO and PEO can be achieved by } \\
\text { students from KV graduates }\end{array}$ & 2.50 & Intermediate \\
\hline \multirow{2}{*}{$\begin{array}{l}\text { explain the element of assessment found in the } \\
\text { OBE approach }\end{array}$} & 2.73 & Intermediate \\
\hline & 2.82 & Intermediate \\
\hline
\end{tabular}

Analysis on the Constraints Faced by Vocational College Lecturers in Implementing the OBE Approach

Table 8 presents the analysis of the constraints faced by KV lecturers in implementing the OBE approach. Based on this analysis, it was clear that 343 respondents (93.2\%) agreed that limited teaching and learning materials have interfered with the planning process using the OBE approach. Meanwhile, shortage of infrastructures such as lecture halls, workshops and inadequate basic equipment hampered the implementation of OBE as 333 respondents $(90 \%)$ agreed with this item. For the next constraint item, the respondents disagreed with the constraint as shown in Table 1.8. 
Table 8

Analysis on the constraints faced by KV lecturers in implementing the OBE approach

\begin{tabular}{|c|c|c|}
\hline Item & $\begin{array}{l}\text { A } \\
\text { (f) } \\
(\%) \\
\end{array}$ & $\begin{array}{l}\text { DA } \\
\text { (f) } \\
(\%)\end{array}$ \\
\hline $\begin{array}{l}\text { Limited teaching and learning materials interfered with the } \\
\text { planning process using the OBE approach. }\end{array}$ & $\begin{array}{l}343 \\
93.2 \%\end{array}$ & $\begin{array}{l}25 \\
6.8 \%\end{array}$ \\
\hline $\begin{array}{l}\text { Inadequate infrastructures such as lecture halls, workshops and } \\
\text { inadequate basic equipment interfered with OBE } \\
\text { implementation. }\end{array}$ & $\begin{array}{l}333 \\
90 \%\end{array}$ & $\begin{array}{l}35 \\
10 \%\end{array}$ \\
\hline $\begin{array}{l}\text { The KV management staff has never held a briefing on OBE to } \\
\text { lecturers. }\end{array}$ & $\begin{array}{l}56 \\
15.3 \%\end{array}$ & $\begin{array}{l}312 \\
84.7 \%\end{array}$ \\
\hline $\begin{array}{l}\text { I'm more comfortable using existing teaching methods than using } \\
\text { the OBE approach. }\end{array}$ & $\begin{array}{l}149 \\
40.4 \%\end{array}$ & $\begin{array}{l}219 \\
59.6 \%\end{array}$ \\
\hline $\begin{array}{l}\text { I do not want to accept new things in education because I am } \\
\text { comfortable with conventional methods. }\end{array}$ & $\begin{array}{l}38 \\
10.4 \%\end{array}$ & $\begin{array}{l}330 \\
89.6 \%\end{array}$ \\
\hline
\end{tabular}

\section{Discussion}

This study is an analysis of the understanding and readiness of vocational college lecturers on OBE approach in teaching and learning dimension. This study also examines the constraints faced by KV lecturers in implementing the OBE approach. The mean for the eight items scoring in comprehension portion was above 3.0, while the other two items were in the intermediate level mean of 2.97. This indicates that KV lecturers' understanding of the OBE's approach to teaching and learning is at a high level. From the analysis conducted, KV lecturers have knowledge of PEO, PLO, CLO, LO and outcome-based assessments. They also have the knowledge of the concepts of Face to face (F2F), None face to face (NF2F) and Formal Assessment in the context of Self Learning Time (SLT). Based on this study, it was also clear that KV lecturers have adopted the OBE approach in the teaching methodology. This situation indicates that the lecturers have understood the purpose and importance of the OBE approach to be adopted in KV. However, there were also lecturers who were not motivated to implement teaching and learning using the OBE approach, which showed a moderate level mean (mean $=2.97$ ). In terms of demographics for this item, male lecturers showed a low level of agreement to implement OBE in teaching. This finding is consistent with the study of Dahdi and Iksan (2018) who stated that efforts to enhance vocational education under the KPM would be successful if KV lecturers are able to improve their level of competence in knowledge, skills and attitudes as well as understanding. This study also discovered that KV lecturers agreed that the OBE approach can foster a culture of innovation among students and that it can produce students who are successful and balanced in terms of cognitive and psychomotor as well as affective. The analysis of this study is supported by Yusof et al (2014) study, which stated that the application of OBE in teaching can produce creative and innovative graduates. This is also in line with a study by Raof et al (2021) which mentioned that students in the TVET field need to be provided with the creativity and innovation embedded in their learning.

Overall, from the aspect of lecturers' readiness in implementing OBE, the mean obtained was intermediate (2.82). Most of the lecturers agreed that the vocational college management has encouraged them to use the OBE approach in teaching and learning dimension. KV 
lecturers were also highly motivated to improve their OBE knowledge as they were seen prepared for courses/seminars aimed at enhancing teaching and learning performance using the OBE approach by showing a mean score of 3.22. The findings of this study are in line with those by Easterly (2017) stating that lecturers should be given the opportunity to attend seminars on teaching methods to increase motivation in presentation techniques. This situation can be explained further when the findings of this study also demonstrated that KV lecturers were prepared to face the challenges of implementing OBE in teaching and learning and to apply appropriate methods of teaching and learning using OBE approach with the mean above 3.01 each. Demographically, the respondents with the duration of service between 6 to 20 years were seen to be more prepared and motivated to implement OBE in their vocational colleges. This situation may have occurred because the lecturers who have been serving for a long period may prefer to use traditional methods and find it difficult to accept change. This coincides with the findings of a study by Suhaimi (2013) who stated that traditional teaching methods are the choice of teachers who have been serving for a long period. KV lecturers were also seen ready to be provided with the opportunity to design teaching and learning materials using the OBE approach and to brief students on OBE with a mean of 2.71. However, some items of readiness were seen at an intermediate level and close to the low level. This study also demonstrated that the lecturers who have just served between 1-5 years were not ready to be interviewed by the MQA. The data shows that KV lecturers were not yet ready to be selected for an interview by the MQA Review Panel with a mean of 2.49. In addition, it was showed that lecturers were not ready to explain how CLO, PLO, PEO can be achieved by KV students and graduates with a mean of 2.50. This result shows that vocational college lecturers are not fully prepared to implement OBE approach.

The final discussion of this study was on the data constraints faced by KV lecturers in implementing the OBE approach. The data showed that 343 lecturers (93.2\%) agreed that limited teaching and learning materials have interfered with the planning process using the OBE approach. The next constraint faced by KV lecturers was the lack of infrastructures such as lecture halls, workshops and inadequate basic equipment that interfered with the implementation of OBE, which displayed 333 lecturers (90\%) who agreed with this statement. This finding is in line with the finding of Yaman et al (2009) stating that the problems exist that make OBE approach unsuccessful include the constraints in terms of classroom infrastructure, workshops and basic needs, which are inadequate for a large student ratio.

\section{Conclusion}

The OBE system encourages students to explore the course content in a way that can help them in learning. The OBE approach can produce students who are creative, innovative and competitive based on the approach that gives them experience. Specifically, this OBE approach encompasses all curriculum components comprising cognitive, psychomotor and affective. The content structure of the course is designed to develop skills, knowledge and values through the teaching methods compiled. Each student will have an experience in terms of teamwork and leadership when the OBE approach is used as each course offered at the KV has outlined the element of PLO. The end of the assessment program is done by focusing on the learning outcomes that have been outlined. The final assessment does not put pressure on students because the OBE approach has outlined the students' achievement and targets. Theoretically, OBE emphasises students' success rather than failure. The assessment method in the OBE approach provides students with the opportunity to demonstrate what they have learned and what they already know. Therefore, the appreciation, understanding and 
readiness of KV lecturers on the implementation of teaching and learning using OBE approach is highly expected in curriculum delivery. Lecturers are the lifeblood in imparting knowledge to students. Therefore, the mastery, understanding and readiness of KV lecturers on the OBE approach is essential. This is because, studies have proven that OBE can give a positive effect on the students' success as it is a system that is relevant to the current progress of the country. Through this OBE approach, the KV students and graduates produced can meet the job market in technical and vocational fields. Nonetheless, the full support from the MOE, BPLTV and the management of vocational colleges is very much needed to ensure that this OBE practice can achieve the next goal of KV to become a superior technical and vocational education leader.

This research has examined the level of understanding and readiness of lecturers on OBE approach using only quantitative approach. In addition, this study only tested the lecturers' understanding in principle and not in depth. Therefore, in the future, it is suggested that studies in the form of mix methods can be implemented so that this study is more explored. In addition, the researcher also proposed a study that aims to test the level of knowledge of $\mathrm{KV}$ lecturers on the OBE approach by conducting tests.

\section{Acknowledgments}

We would like to acknowledge the support of Scholarship and Finance, Ministry of Education Malaysia under HLP 2019-2022. We would also like to express my gratitude to the Universiti Teknologi Malaysia (UTM Fundamental Research-UTMFR 21H02) and all agricultural lecturers from agricultural vocational colleges who are willing to participate in this study.

\section{References}

Arifin, N. A. (2013). Pelaksanaan Outcomes Based Education (OBE) Dalam Kalangan Pensyarah di Fakulti Pendidikan Teknikal dan Vokasional. (Implementation of Outcomes Based Education (OBE) Among Lecturer at the Faculty of Technical and Vocational Education). [Unpublished master dissertation] Universiti Tun Hussein Onn Malaysia.

Arshad, M. Z., \& Mustapha, R. (2017). Hubungan antara beban tugas dengan efikasi diri dan kepuasan kerja pensyarah di Kolej Vokasional. [The relationship between workload and self -efficacy and job satisfaction of lecturers in Vocational Colleges]. Sains Humanika 9:15(2017)35-43. https://doi.org/10.11113/sh.v9n1-5.1174

Borsoto, L. D., Lescano, J. D., Maquimot, N. I., Santorce, M. J. N., Simbulan, A. F., \&

Pagcaliwagan, A. M. (2014). Status of implementation and usefulness of outcomes-based education in the engineering department of an Asian university. International Journal of Multidisciplinary Academic Research, 2(4), 14-25.

Butler, M. (2004). Outcomes Based/ Outcomes Focused Education Overview. A Review Literature. Education Department of Western Australia.

Chua, Y. P. (2013). Asas statistik penyelidikan analisis data skala likert buku 3[Statistical basis of likert scale data analysis research book 3] (2nd ed). Mc Graw Hill Education.

Cohen, L., Manion, L. M., \& Morrison, K. (2005). Research Methods in Education (6th Edition). Routledge.

Creswell, J. W. (2012). Educational Research: Planning, Conducting, and Evaluating Quantitative and Qualitative Research, (4th ed.). Merrill.

Dahdi, H., \& Iksan, Z. (2018). Pembelajaran Berasaskan Hasil dalam Pendidikan Tinggi (Outcome Based Education, OBE) [Outcome-Based Education, OBE in Higher Education 
]. Retrived from https://sted18.files.wordpress.com/2018/12/1-50-hema-dahdizanaton-iksan.pdf

Damit, M. A., \& Omar, M. K. (2018). Pelaksanaan Outcome Based Education (OBE) di Kolej Vokasional Malaysia. [Implementation of Outcome Based Education (OBE) in Colleges Malaysian Vocational].Graduate Research In Education Seminar (GREduc) 2018 Revolutionaling Research Practices in Education and Human Resource Development.

Darusalam, G., \& Hussin. S. (2018). Metodologi penyelidikan dalam pendidikan [Research Methodology in education] (2nd ed.). Penerbit Universiti Malaya.

Easterly III, R. G., \& Myers, B. E. (2017). Characteristics of Enthusiastic and Growing SchoolBased Agricultural Education Teachers: A Delphi Approach. Journal of Agricultural Education, 58(2), 1-19. https://doi.org/10.5032/jae.2017.02001

Hair, J. F., Anderson, R. E., Tatham, R. L., \& Black, W. C. (1998). Multivariate data analysis (5 $5^{\text {th }}$ ed.). Upper Saddle River, NJ.Hair, J. F., Black, W. C., Babin, B. J., \& Anderson, R. E. (2010).Multivariate data analysis. Englewood Cliffs, NJ: Prentice Hall.

Hassan, S. A., Admodisastro, N. I., Kamaruddin, A., Baharom, S., \& Pa, N. C. (2016). Developing a learning outcome-based question examination paper tool for Universiti Putra Malaysia. International Education Studies, 9(2), 132-140.

https://dx.doi.org/10.5539/ies.v9n2p132

Killen, R. (2007). Outcome-based Education: Principles and Possibilities, Unpublished manuscript, University of Newcastle, Faculty of Education.

Krejcie, R. V., \& Morgan, D. W. (1970). Determining sample size for research activities. Educational and Psychological Measurement, 30, 607-610.

Malaysia Qualification Agency. (2018). Code of practice for programme accreditation (2 ${ }^{\text {nd }}$ Edition).Cyberjaya, Malaysia: Malaysian Qualification Agency.

Malaysian Qualifications Agency. (2018). Malaysian qualifications framework (MQF) $\left(2^{\text {nd }}\right.$ Edition). Cyberjaya, Malaysia: Malaysian Qualifications Agency.

Murad, N. F. A., \& Hamzah, M. I. M. (2016). Tahap kesediaan tenaga pengajar kolej vokasional terhadap pembelajaran berasaskan hasil, obe dan hubungannya dengan kualiti penyampaian kurikulum. [The level of readiness of vocational college teachers towards outcome -based learning, OBE and its relationship with the quality of curriculum delivery]. Retrived from https://sted18.files.wordpress.com/2018/12/1-48-norfadhlina-ahmad-murad-mohd-izham-mohd-hamzah.pdf

Raof, S. A., Musta'amal, A. H., Zamzuri, F. K., \& Salleh, M. H. (2021). Validity and reliability of students perceptions on OBE approach in Malaysian VC using Rasch model. Journal of Innovation in Educational and Cultural Research, 2(2), 44-50.

https://doi.org/10.46843/jiecr.v2i2.30

Spady, W. G. (1994). Outcome-Based Education - Critical Issues and Answer. Retrieved from https://eric.ed.gov/?id=ED380910

Spady, W. G., \& Marshall, K. J. (1991). Beyond traditional outcome-based education. Educational leadership, 49(2), 67-72. Retrieved from https://eric.ed.gov/?id=EJ432789

Tucker, B. (2004). Literature Review: Outcomes-Focused Education In Universities. Learning Support Network, Curtin University of Technology.

Yaman, A., Azemi, N. C., \& Shamsudin, F. (2009). Kesediaan pensyarah dalam perlaksanaan pengajaran dan pembelajaran (pnp) menggunakan pendekatan outcome based education (OBE) di Politeknik Port Dickson. In Seminar Pengajaran dan Pembelajaran Berkesan

Yusoff, Y. M., Fuaad, N. F. A., Yasin, R. B. M., \& Tawil, N. M. (2014). Achievement of program 
outcomes in outcome based education implementation-a meta analysis. In Proceedings of the 2014 international conference on industrial engineering and operational management, Bali, Indonesia (pp. 7-9).

Zain, N. M., Hadi, A. A., \& Hamid, K. A. (2016). Outcome based education: A perception from private health sciences graduating scholars in Malaysia. European Journal of Education Studies. 2(6),78-79. https://dx.doi.org/10.5281/zenodo.160233 